\title{
PROFIL PEMAHAMAN MATEMATIS SISWA DALAM MENYELESAIKAN MASALAH BERDASARKAN KEMAMPUAN MATEMATIKA DI SMK MUHAMMADIYAH 1 BARON
}

\author{
ABDUR ROCHIM \\ SMK Muhammadiyah 1 Baron \\ Email : abdur.rochim88@gmail.com
}

\begin{abstract}
ABSTRAK
Matematika memiliki karakteristik khusus yaitu objek kajian yang abstrak. Karena kekhususannya ini maka dalam mempelajari matematika diperlukan pemahaman matematis. Pemahaman matematis dalam menyelesaikan masalah matematika berbeda antar setiap siswa. Perbedaan ini dikarenakan setiap siswa memiliki kemampuan matematika yang berbeda. Tujuan penelitian ini adalah untuk mendeskripsikan (1) profil pemahaman matematis siswa berkemampuan matematika tinggi dalam menyelesaikan masalah (2) profil pemahaman matematis siswa berkemampuan matematika sedang dalam menyelesaikan masalah (3) profil pemahaman matematis siswa berkemampuan matematika rendah dalam menyelesaikan masalah. Penelitian ini merupakan penelitian deskriptif kualitatif dengan subjek penelitian kelas XI SMK Muhammadiyah 1 Baron berjumlah 3 siswa. Pemilihan subjek penelitian berdasarkan pada kemampuan matematika siswa yaitu kemampuan matematika tinggi, sedang dan rendah. Teknik pengumpulan data dalam penelitian ini menggunkan teknik tes pemecahan masalah dan wawancara. Keabsahan data yang digunakan dalam penelitian ini menggunakan triangulasi waktu. Berdasarkan hasil analisis data diperoleh hasil bahwa (1) Profil pemahaman matematis berkemampuan matematika tinggi dalam menyelesaikan masalah fungsi kuadrat adalah subjek membaca masalah sampai paham, menuliskan dengan benar apa yang diketahui dan ditanyakan, melakukan eksplorasi masalah dengan tepat, memilih strategi penyelesaian masalah dengan tepat, menacari jawaban dengan melalukan perhitungan aljabar dengan tepat serta melakukan pemeriksaan jawaban kembali dari solusi yang diperoleh. (2) Profil pemahaman matematis berkemampuan matematika sedang dalam menyelesaikan masalah fungsi kuadrat adalah subjek membaca masalah sampai paham, menyebutkan dengan benar apa yang diketahui dan ditanyakan, melewatkan eksplorasi masalah, menacari jawaban dengan melalukan perhitungan aljabar walaupun diperoleh jawaban yang kurang tepat serta tidak melakukan pemeriksaan jawaban kembali. (3) Profil pemahaman matematis berkemampuan matematika rendah dalam menyelesaikan masalah fungsi kuadrat adalah subjek membaca masalah sampai paham, menyebutkan dengan benar apa yang diketahui dan ditanyakan, melewatkan eksplorasi masalah, menacari jawaban dengan melalukan perhitungan aljabar namun diperoleh jawaban yang kurang tepat serta tidak melakukan pengecekan jawaban kembali.
\end{abstract}

Kata Kunci: Kemampuan Matematika, Pemahaman Matematis, Pemecahan Masalah

\begin{abstract}
Mathematics has a special characteristic that is an abstract object of study. Because of this specificity, learning mathematics requires mathematical understanding. Mathematical understanding in solving mathematical problems is different between each student. This difference is because each student has different mathematical abilities. The purpose of this study was to describe (1) the profile of mathematical understanding of students with high mathematics ability in solving problems (2) the profile of mathematical understanding of students with moderate mathematics ability in solving problems (3) the profile of mathematical understanding of students with low mathematics ability in solving problems. This research is a qualitative descriptive study with 3 students as the subject of class XI SMK Muhammadiyah 1 Baron. The selection of research subjects was based on students' mathematical abilities, namely high, medium and low mathematical abilities. Data collection techniques in this study using problem
\end{abstract}




\section{VOCATIONAL : Jurnal Inovasi Pendidikan Kejuruan Vol. 1 No. 4 Oktober 2021 e-ISSN : 2774-6283 | p-ISSN : 2775-0019}

solving test techniques and interviews. The validity of the data used in this study used time triangulation. Based on the results of data analysis, the results showed that (1) The profile of mathematical understanding with high mathematical ability in solving quadratic function problems is the subject of reading the problem until it understands, writing correctly what is known and asked, conducting problem exploration appropriately, choosing the right problem solving strategy, looking for answers by doing algebraic calculations correctly and checking the answers back from the solutions obtained. (2) The profile of mathematical understanding with moderate mathematical ability in solving quadratic function problems is that the subject reads the problem until he understands, correctly states what is known and asked, skips problem exploration, looks for answers by doing algebraic calculations even though inaccurate answers are obtained and does not check answer back. (3) The profile of mathematical understanding with low mathematical ability in solving quadratic function problems is that the subject reads the problem until he understands, correctly states what is known and asked, skips problem exploration, looks for answers by doing algebraic calculations but gets inaccurate answers and does not check answer back.

Keywords: Mathematical Ability, Mathematical Understanding, Problem Solving

\section{PENDAHULUAN}

Matematika pada hakikatnya merupakan ilmu tentang struktur yang terorganisasi yaitu matematika berkembang mulai dari unsur yang tidak terdefinisikan, ke unsur yang didefinisikan, ke postulat/aksioma, ke teorema sehingga membentuk sistem yang saling berhubungan dan terorganisir baik (Ibrahim \& Suparni, 2012: 8). Matematika sebagai ilmu yang tersusun rapi dalam berbagai struktur dengan hierarkinya masing-masing mempunyai karakteristik khusus, salah satunya aadalah objek kajian yang abstrak (Soejadi, 2007: 8). Objek matematika dapat dibedakan menjadi objek langsung dan objek tidak langsung. Objek tidak langsung matematika merupakan hal-hal yang mengiringi perolehan belajar objek langsung seperti kemampuan pemahaman matematis, kemampuan pemecahan masalah, dan sebagainya (Susanto, 2015: 9).

Pemahaman matematis diperlukan dalam mempelajari matematika. Pemahaman matematis menurut Skemp (dalam Hendriana, Rohaeti \& Sumarmo, 2017: 4) adalah terdapat dua jenis kemampuan Pemahaman yaitu: (1) pemahaman instrumental yang artinya hafal sesuatu secara terpisah atau dapat menerapkan sesuatu pada perhitungan rutin/sederhana, mengerjakan sesuatu secara algoritmik. (2) pemahaman relasional yang berarti dapat melakukan perhitungan secara bermakna pada permasalahan-permasalahan yang lebih luas, dapat mengaitkan suatu konsep/prinsip lainnya dan sifat pemakainnya lebih bermakna. Menurut NCTM (dalam Hendriana et al., 2017: 7) Rumusan indikator pemahaman matematis siswa adalah Mendefinisikan konsep secara verbal dan tulisan; Mengidentifikasi dan membuat contoh dan bukan contoh; Menggunakan simbol-simbol untuk mempresentasikan suatu konsep; Mengidentifikasi sifat-sifat suatu konsep dan mengenal syarat yang menentukan suatu konsep; Mengenal berbagai makna dan interpretasi konsep; Membandingkan dan membedakan konsep.

Pemahaman matematis mendukung siswa dalam menyelesaikan masalah matematika. Pemecahana masalah merupakan suatu proses berpikir yang diarahkan untuk memperoleh jawaban dari masalah (Mairing, 2018). Pemecahan masalah dapat juga didefinisikan sebagai suatu pemikiran yang terarah secara langsung untuk menemukan suatu solusi/jalan keluar untuk suatu maslah yang spesifik (Solso, 2019). Langkah penyelesaian masalah dalam penelitian ini menggunakan teori Krulik dan Rudnick. Teori ini lima fase dalam proses pemecahan masalah yang disebut heuristik yaitu: (1) Membaca dan memikirkan (Read and think). (2) Mengeskplorasikan dan merencanakan (Explore and Plan). (3) Memilih suatu strategi (Select a strategy). (4) Mencari suatu jawaban (Find an answer) (5) Meninjau kembali dan mendiskusikan (Reflect and extend) (Ma'rufi, 2015:67). Indikator pemahaman matematis dalam menyelesaikan masalah menggabungkan rumusan indikator pemahaman matematis dan lima fase tahap pemecahan masalah Krulik \& Rudnick. 
Pemahaman matematis (mathematical Understanding) dan kemampuan pemecahan masalah (mathematical problem solving) adalah kemampuan matematis yang penting dan harus dimiliki siswa dalam belajar matematika (Rochim, Herawati \& Nurwiani, 2021; Rochim, 2021). Kedua kemampuan ini juga tertuang dalam tujuan kurikulum SMK/MAK tahun 2018 pada aspek pengetahuan yaitu pemahaman dan pada aspek ketrampilan yaitu kemampuan pemecahan masalah. Pentingnya pemahaman matematis sesuai dengan pendapat Santrock (dalam Hendriana et al., 2017: 3) bahwa pemahamn konsep adalah kunci dari pembelajaran. Demikian pula pemahaman matematis merupakan landasan untuk berpikir dalam menyelesaikan persoalan-persoalan matematika maupun masalah kehidupan nyata. Selain itu kemampuan pemahaman matematis mendukung pada pengembangan kemampuan matematis lainnya, seperti kemampuan komunikasi, pemecahan masalah, penalaran, koneksi, reprentasi, berpikir kritis dan kreatif.

Selain pemahaman matematis, pentingnya memiliki kemampuan pemecahan masalah matematika bagi para siswa menurut Mairing (2018, 1-15) adalah bahwa kemampuan pemecahan masalah merupakan kompetensi dasar yang harus dimiliki siswa dalam belajar matematika; Mengembangkan sikap tekun dan pantang menyerah melalui belajar menyelesaikan masalah matematika; Mengembangkan kemampuan berpikir kritis dan kreatif melalui belajar menyelesaikan masalah matematika; Masalah matematika mendorong siswa melakukan pengaitan antarkonsep matematis sehingga konsep-konsep tersebut bermakna dalam pikiran siswa; Masalah matematika membuat siswa memahami manfaat konsep-konsep matematika dalam kehidupan sehari-hari; Pembelajaran yang menggunakan masalah dikelas memberi kesempatan pada siswa untuk mengembangkan kepercayaan diri, kemampuan komunikasi dan kemampuan kerjasama. Irhamna (2017) dalam penelitiannya menuliskan bahwa kemampuan pemecahan masalah meningkat setelah dilakukan pembelajaran pemecahan masalah dengan strategi Krulik dan Rudnick.

Fakta awal dilapangan menunjukkan bahwa terdapat siswa yang memiliki kemampuan matematika tinggi, sedang dan rendah. Penggolongan ini diperoleh dari hasil penilaian akhir semester ganjil murni. Siswa berkemamampuan matematika rendah, salah satunya disebabkan oleh pemahaman terhadap konsep matematika yang rendah pula. Siswa cenderung belajar matematika dengan menghafal rumus dan tanpa disertai dengan keterkaintan konsep-konsep matematika. Belajar dengan menghafal hanya mampu memberikan contoh dan bukan contoh dari suatu konsep matematika tetapi untuk penggunaan simbol, menginterpretasi konsep, mengindentifikasi konsep serta membedakan konsep belum maksimal. Kemampuan pemahaman konsep matematika yang rendah berbanding lurus dengan kemampuan pemecahan masalah yang rendah pula. Siswa berkemampuan matematika rendah dalam menyelesaikan masalah adalah membaca masalah dengan tergesa-gesa, strategi penyelesaiannya tanpa rumus dan melewatkan pemeriksaan kembali hasil jawaban yang diperoleh. Kemampuan matematika siswa tinggi, sedang dan rendah tentunya memliki profil pemahaman matematis yang berbeda dalam menyelesaikan masalah matematika. Oleh karena itu untuk memberikan umpan balik dan bantuan yang tepat maka guru perlu mengetahui deskripsi pemahaman matematis siswa dalam menyelesaikan masalah matematika. Hasil akhirnya adalah perbaikan kualitas pembelajaran dan peningkatan prestasi belajar siswa.

Fakta dan kondisi siswa dilapangan yang telah diuraikan juga selaras dengan beberapa hasil penelitian terdahulu. Hasil penelitian Siki, Djong, \& Jagom (2021) meyimpulkan bahwa siswa berkemampuan matematika tinggi mampu menyelesaikan pemecahan masalah dan memenuhi indikator penerjemahan, penafsiran dan ekstrapolasi; siswa berkemampuan matematika sedang juga memenuhi indikator penerjemahan, penafsiran dan ekstrapolasi; sedangkan siswa berkemampuan matematika rendah hanya memenuhi indikator penerjemahan dan penafsiran. Fahrudin, Mustangin, \& Faradiba (2021) dalam penelitiannya menyatakan bahwa siswa SMP berkemampuan matematika tinggi mampu mencapai semua indikator pemecahan masalah yaitu memahami masalah, merencanakan masalah, menyelesaikan masalah, dan memeriksa kembali secara sistematis; siswa berkemampuan matematika sedang 


\section{VOCATIONAL : Jurnal Inovasi Pendidikan Kejuruan Vol. 1 No. 4 Oktober 2021 e-ISSN : 2774-6283 | p-ISSN : 2775-0019}

mampu mencapai tiga indikator pemecahan masalah yaitumemahami masalah, merencanakan penyelesaian masalah, dan menyelesaikan masalah secara sistematis; dan siswa yang berkemampuan matematika rendah hanyamampu memenuhi dua indikator pemecahan masalah yaitu memahami masalah dan merencanakan penyelesaian masalah secara sistematis.

Hasil penelitian lain yaitu Meilando, Idris \& Murdiana (2017) menyatakan bahwa (1) pada tahap memahami masalah siswa berkemampuan matematika tinggi, sedang dan rendah melakukan pembacaan masalah secara berulang serta menggunakan pengetahuannya dalam memahami masalah, (2) tahap membuat rencana pemecahan masalah, subjek berkemampuan matematika tinggi dan sedang memiliki rencana pemecahan masalah dengan menggunakan rumus, sedangkan subjek berkemampuan matematika rendah hanya langsung mengalikan (3) tahap melaksanakan rencana pemecahan masalah, subjek berkemampuan matematika tinggi, sedang dan rendah melaksanakan sesuai rencana, menghubungkan konsep berupa simbol-simbol dan mengoperasikannyauntuk menemukan solusi dari masalah yang diberikan (4) tahap memeriksa kembali hasil pekerjaan, subjek berkemampuan matematika tinggi melakukan pemeriksaan kembali hasil pekerjaannya sebelum dan sesudah penyelesaian akhir jawaban, sedangkan subjek berkemampuan matematika sedang dan rendah tidak melakukan pemeriksaan kembali terhadap hasil pengerjaannya. Pada penelitian ini peneliti ingin mendiskripsikan (1) profil pemahaman matematis siswa berkemampuan matematika tinggi dalam menyelesaikan masalah (2) profil pemahaman matematis siswa berkemampuan matematika sedang dalam menyelesaikan masalah (3) profil pemahaman matematis siswa berkemampuan matematika rendah dalam menyelesaikan masalah.

\section{METODE PENELITIAN}

Penelitian ini merupakan jenis penelitian deskriptif kualitatif karena data yang dikumpulkan dalam bentuk kata-kata atau gambar-gambar bukan hanya bilangan-bilangan. Penelitian ini dilakasanakan di Sekolah Menengah Kejuruan (SMK) Muhammadiyah 1 Baron pada semester ganjil tahun pelajaran 2020/2021 dengan calon subjek adalah siawa kelas XI berjumlah 11 siswa. Kemudian dipilih tiga subjek berdasarkan kemampuan matematika tinggi, sedang dan rendah. Pemilihan subjek ini berdasarkan nilai Penilaiaan akhir semeseter ganjil murni dan yang memiliki komunikasi lancar.

Teknik pengumpulan data yang digunakan dalam penelitian ini adalah teknik tes dan wawancara. Instrumen yang digunakan dibagi menjadi dua yaitu instrumen utama dan instrumen pendukung. Instrumen utama adalah peneliti sendiri, sedangkan instrumen pendukung adalah lembar tes pemecahan masalah fungsi kuadrat dan pedoman wawancara. Proses validasi instrumen pendukung penelitian yaitu tes pemecahan masalah fungsi kuadrat I dan II, serta Pedoman wawancara dilakukan oleh dua validator ahli Pendidikan Matematika yaitu Dosen dan guru matematika. Uji Keabsahan data dalam penelitian ini menggunakan triangulasi waktu. Triangulasi waktu berarti bahwa pemberian tes pemecahan masalah fungsi kuadrat dan wawancra diberikan minimal dua kali dalam waktu yang berbeda. Jika hasil uji menghasilkan data yang berbeda, maka dilakukan secara berulang-ulang sehingga sampai ditemukan data yang ajeg atau kerdibel. Dalam penelitian ini pemberian tes pemecahan masalah fungsi kuadrat dan wawancara dilaksanakan dalam dua tahap dan sudah diperoleh keajegan data. Teknis analisis data dilakukan dengan tahapan reduksi data, penyajian data dan simpulan.

\section{HASIL DAN PEMBAHASAN}

Subjek berkemampuan matematika tinggi (S01) dalam menyelesaikan masalah fungsi kuadrat membaca terlebih dahulu masalah sampai paham dan memberi coretan garis pada masalah tersebut. Ketika dikonfirmasi dengan wawancara, subjek menjelaskan bahwa saat diberikan masalah fungsi kuadrat yang dilakukan adalah memahami soal, membaca, dan memberi garis-garis pada masalah tersebut. Hal ini sejalan dengan langkah pertama pemecahan 
masalah Krulik dan Rudnick (Ma'rufi, 2015) yaitu Read and Think yang menyatakan tahap awal menyelesaikan masalah adalah membaca dan berpikir. Pendapat ini didukung juga dengan hasil penelitian Meilando, Idris \& Murdiana (2017) menyatakan bahwa siswa berkemampuan matematika tinggi, sedang dan rendah melakukan pembacaan masalah secara berulang serta menggunakan pengetahuannya dalam memahami masalah.

Subjek S01 menuliskan dengan benar apa yang diketahui, apa yang ditanyakan dan fakta yang belum diketahui daria masalah fungsi kuadrat yang diberikan. Hal ini dapat dilihat pada hasil tes seperti pada gambar berikut:

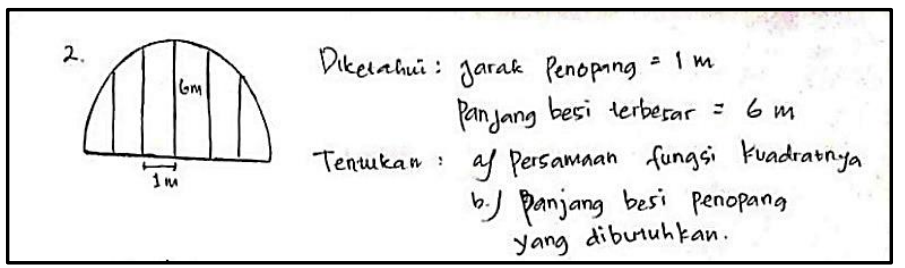

Gambar. 1 Subjek menuliskan apa yang diketahui dan ditanyakan

Ketika dikonfirmasi dengan wawancara, subjek menjelaskan sama seperti yang sudah ditulis pada jawaban tes. Hal ini sejalan dengan langkah pertama pemecahan masalah Krulik dan Rudnick (Ma'rufi, 2015) yaitu Read and Think yang salah satu indikatornya adalah menuliskan apa yang diketahui dan ditanyakan. Pernyataan ini juga didukung oleh Hasil penelitian Siki, Djong, \& Jagom (2021) yang meyimpulkan bahwa siswa berkemampuan matematika tinggi mampu menyelesaikan pemecahan masalah dan memenuhi indikator penerjemahan yaitu siswa mampu menuliskan apa yang diketahui dan ditanyakan dengan tepat

Subjek S01 mengeksplorasi masalah fungsi kuadrat dengan cara menstransformasi gambar ke dalam bidang kartesius, seperti gambar berikut:

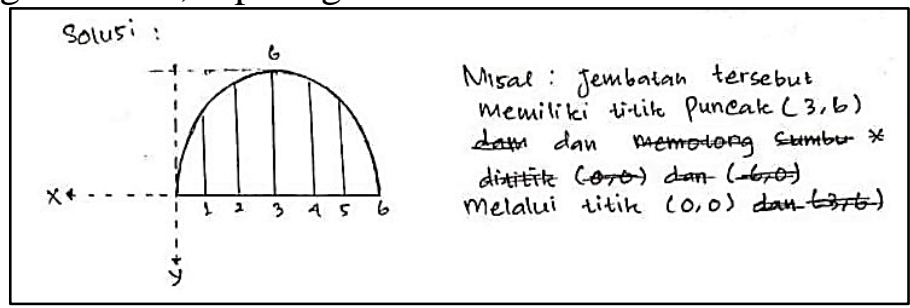

Gambar 2. Subjek S01 mengeksplorasi masalah

Pada saat wawancara, subjek S01 menjelaskan bahwa Subjek mengeksplorasi masalah fungsi kuadrat dengan mengidentifikasi sifat-sifat konsep fungsi kuadrat. Langkah-langkahnya seperti mencari persamman fungsi kuadrat dengan cara menstransformasi parabola itu pada bidang kartesius. Subjek menentukan kecukupan data atau syarat konsep fungsi kuadrat yaitu mencari persamaman kuadrat melalui titik puncak dan titik lain yang dilalui parabola itu. Subjek mengorganisasikan atau menyajikan data dalam bentuk gambar Pernyataan ini sesuai dengan langkah pemecahan maslah Krilik \& Rudnick (Ma'rufi, 2015) pada tahap Explore and plan yaitu mengeksplorasi dan merencanakan masalah. Pernyataan ini juga didukung dengan hasil penelitian Siki, Djong, \& Jagom (2021) yang meyimpulkan bahwa siswa berkemampuan matematika tinggi mampu menyelesaikan pemecahan masalah dan memenuhi indikator penerjemahan yaitu siswa mampu menterjemahkan ke dalam model matematika dengan tepat.

Subjek S01 menggunakan strategi penyelesaian masalah dengan menggunakan rumus fungsi kuadrat. Hal ini dapat dilihat dari hasil tes berikut: 


$$
\text { a). } \begin{aligned}
y & =a(x-x p)^{2}+y p \\
0 & =a(0-3)^{2}+6 \\
0 & =a(-3)^{2}+6 \\
0 & =9 a+6 \\
a & =-2 / 3 .
\end{aligned}
$$

\section{Gambar 3. Subjek S01 memilih strategi penyelesaian masalah}

Pada saat wawancara, subjek S01 menyatakan bahwa penggunaan rumus fungsi kuadrat untuk menyelesaikan masalah yang diberikan. Subjek merencakan langkah penyelesaian masalah dengan cara mencari persamaan fungsi kuadart dengna menggunakan rumus fungsi yang melalui titik puncak dan titik lain. Subjek mengenal berbagai makna dan interpretasi konsep fungsi kuadrat yaitu bahwa untuk mencari panjang besi keseluruhan dengan memasukkan nilai titik yang sudah di sesuaikan dengan gambar ke dalam rumus fungsi kemudian di jumlahkan. Hal ini sesuai dengan langkah penyelesaian Krulik \& Rudnik (Ma'rufi, 2015) yaitu Select a plan yang berarti memilih sustu strategi. Pernyataan ini juga didukung hasil penelitian Meilando, Idris \& Murdiana (2017) yang menyimpulkan bahwa subjek berkemampuan matematika tinggi memiliki rencana pemecahan masalah dengan menggunakan rumus.

Subjek S01 mencari suatu solusi dari masalah dengan cara melakukan perhitungan aljabar dengan tepat. Hal ini dapat dilihat dari hasil tes berikut:

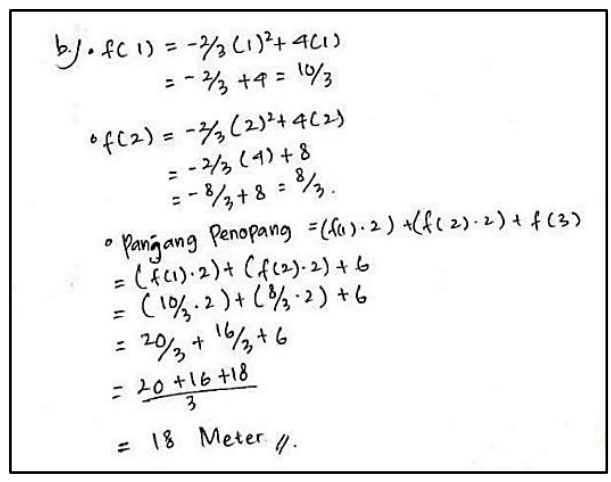

\section{Gambar 4. Subjek S01 mencari suatu jawaban}

Ketika dikonfirmasi dengan wawancara, subjek S01 menjelaskan bahwa Subjek melaksanakan langkah penyelesaian masalah sesuai dengan rencana awal yaitu menggunakan rumus fungsi kuadrat melalui titik puncak dan titik lainnya. Subjek melakukan perhitungan aljabar yaitu subjek melakukan perhitungan matematis terhadap rumus fungsi yang telah ditulis dan menghasilkan jawaban yang benar. Sedangkan untuk perhitungan panjang besi keseluruhan masih salah karena dalam prosesnya masih ada salah perhitungan aljabar. Hal ini sesuai dengan langkah penyelesaian Krulik \& Rudnik (Ma'rufi, 2015) find a answer yaitu mencari suaru jawaban atau solusi dari masalah yang diberikan. Pendapat ini juga sejalan hasil penelitian Meilando, Idris \& Murdiana (2017) menyatakan bahwa subjek berkemampuan matematika tinggi melaksanakan pemecahan masalah sesuai rencana, menghubungkan konsep berupa simbol-simbol dan mengoperasikannya untuk menemukan solusi dari masalah yang diberikan.

Subjek S01 meninjau kembali hasil solusi atau hasil jawaban yang diperoleh dengan mengecek jawaban sebanyak satu kali. Hal ini diketahui dari hasil wawancara kepada subjek yang menyatakan bahwa subjek mengecek ulang jawaban sebanyak satu kali. Hal ini sejalan dengan langkah penyelesaian masalah Krulik \& Rudnik (Ma'rufi, 2015) Reflect and extend yaitu merefleksi dan memperluas. Pernyataan ini juga didukung dengan hasil 
penelitian Meilando, Idris \& Murdiana (2017) subjek berkemampuan matematika tinggi melakukan pemeriksaan kembali hasil pekerjaannya sebelum dan sesudah penyelesaian akhir jawaban.

Subjek berkemampuan matematika sedang (S02) dalam menyelsaikan masalah fungsi kuadrat adalah adalah membaca masalah terlebih dahulu masalah sampai paham. Saat dikonfirmasi dengan wawancara, subjek menjelaskan bahwa saat diberikan masalah fungsi kuadrat yang dilakukan adalah memahami soal dan membaca beberapa kali. Hal ini sejalan dengan langkah pertama pemecahan masalah Krulik dan Rudnick (Ma'rufi, 2015) yaitu Read and Think yang berarti membaca dan berpikir. Pendapat ini sejalan juga dengan hasil penelitian Meilando, Idris \& Murdiana (2017) menyatakan bahwa siswa berkemampuan matematika sedang melakukan pembacaan masalah secara berulang serta menggunakan pengetahuannya dalam memahami masalah.

Subjek S02 melewatkan menulis apa yang diketahau dan apa yang ditanyakan dari masalah fungsi kuadrat yang berikan. Pada saat dikonfirmasi dengan wawancara, subjek menjelesakan bahwa subjek tidak terbiasa menuliska apa yang diketahui dan apa yang ditanyakan ketika menjawab suatu soal. Dengan kata lain subjek terbiasa melangsungkan proses pencarian jawaban. Tetapi ktika ditanya subjek menjawab dengan benar apa yang diketahi dan apa yang ditanyakan yaitu yang diketahui adalah jarak besi penopang, panjang besi terbesar. yang ditanyakan dalam soal yaitu Persamaan fungsi kuadrat, panjang besi penopang. Hal ini sejalan dengan langkah pertama pemecahan masalah Krulik dan Rudnick (Ma'rufi, 2015) yaitu Read and Think yang salah satu indikatornya adalah menyebutkan apa yang diketahui dan ditanyakan. Pernyataan ini juga didukung oleh Hasil penelitian Fahrudin, Mustangin, \& Faradiba (2021) yang meyimpulkan bahwa siswa berkemampuan matematika sedang mampu menyebutkan apa yang diketahui dan apa yang ditanyakan dari masalah yang diberikan.

Subjek S02 melakuakan langkah mengeksplorasi masalah fungsi kuadrat langsung menggunakan rumus. Pada saat wawancara, subjek S02 menjelaskan bahwa subjek mengeksplorasi masalah fungsi kuadrat langsung menggunakan rumus karena data mengenai apa yang diketahui sudah cukup untuk menjawab masalah apa yang ditanyakan. Dengan kecukupan data itu, subjek S02 langsung melanjutkan langkah menjawab masalah mengunakan rumus tersebut. Pernyataan ini juga didukung dengan hasil penelitian Hasil penelitian Fahrudin, Mustangin, \& Faradiba (2021) yang meyimpulkan bahwa siswa berkemampuan matematika sedang kurang mampu mengeksplosari data-data dari masalah yang diberikan.

Subjek S02 menggunakan strategi penyelesaian masalah dengan menggunakan rumus fungsi kuadrat. Hal ini dapat dilihat dari hasil tes berikut:

$$
\begin{aligned}
J=a(x-x P)^{2}+j p=j & =a(0-3)^{2}+6 \\
0 & =a(6)+6 \\
a & =a(6)+6 \\
a & =-12
\end{aligned}
$$

\section{Gambar 5. Subjek S02 memilih suatu stategi penyelesaian masalah}

Pada saat wawancara, subjek S02 menyatakan bahwa menggunaan rumus fungsi kuadrat untuk menyelesaikan masalah yang diberikan. Subjek merencakan langkah penyelesaian masalah dengan cara Mencari persamaan fungsi kuadrat dengan menggunakan subtitusi nilai. Subyek mengenal berbagai makna dan interpretasi konsep fungsi kuadrat yaitu bahwa untuk mencari panjang besi keseluruhan dengan memasukkan nilai titik yang sudah di sesuaikan dengan gambar ke dalam rumus fungsi kemudian di jumlahkan.. Hal ini sesuai dengan langkah penyelesaian Krulik \& Rudnik (Ma'rufi, 2015) yaitu Select a plan yang berarti memilih sustu strategi. Pernyataan ini juga didukung hasil penelitian Meilando, Idris \& Murdiana (2017) yang 
menyimpulkan bahwa subjek berkemampuan matematika sedang memiliki rencana pemecahan masalah dengan menggunakan rumus.

Subjek S02 mencari suatu solusi dari masalah dengan cara melakukan perhitungan aljabar. Hal ini dapat dilihat dari hasil tes berikut:

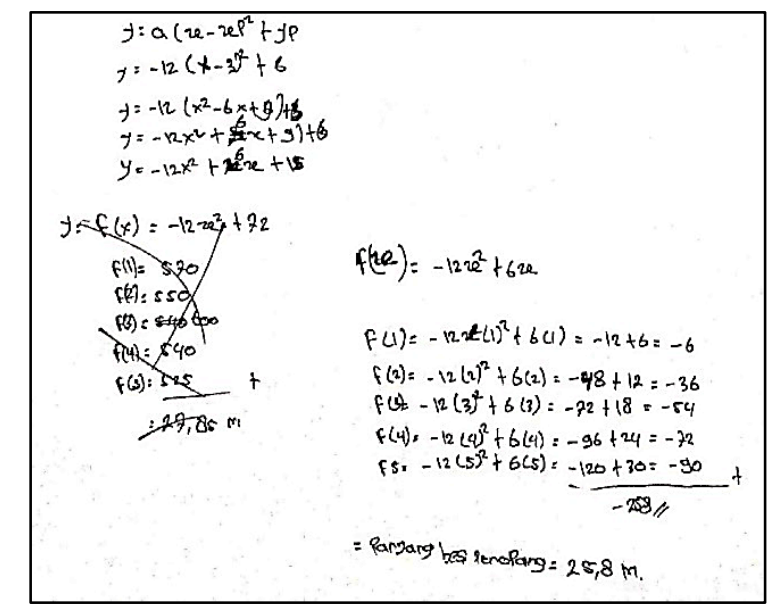

Gambar 6. Subjek S02 mencari suatu jawaban

Ketika dikonfirmasi dengan wawancara subjek S02 menjelaskan bahwa Subjek melaksanakan langkah penyelesaian masalah sesuai dengan rencana awal, menggunakan rumus fungsi kuadrat dan subtitusi nilai. Subjek melakukan perhitungan aljabar yaitu melakukan perhitungan matematis terhadap rumus fungsi yang telah ditulis dan menghasilkan jawaban yang salah. Kesalahan perhitungan disebabkan karena subjek kurang teliti dalam mengerjakan. Terlihat juga coretan-coretan dalam pengerjaan yang mengindikasikan subjek dalam kondisi binggung atau salah perhitungan. Hal ini sesuai dengan langkah penyelesaian Krulik \& Rudnik (Ma'rufi, 2015) find a answer yaitu mencari suaru jawaban atau solusi dari masalah yang diberikan walaupan jawaban nnya kurang tepat. Pendapat ini juga sejalan hasil penelitian Fahrudin, Mustangin, \& Faradiba (2021) yang meyimpulkan bahwa siswa berkemampuan matematika sedang kurang mampu dalam menyelesaikan masalah.

Subjek S02 melewatkan langkah meninjau kembali hasil solusi atau hasil jawaban yang diperoleh. Hal ini diketahui dari hasil wawancara kepada subjek yang menyatakan bahwa subjek tidak mengecek ulang jawaban karena tidak cukup waktu dan sudah stuk. Pernyataan ini juga didukung dengan hasil penelitian Meilando, Idris \& Murdiana (2017) subjek berkemampuan matematika sedang tidak melakukan pemeriksaan kembali hasil pekerjaannya.

Subjek berkemampuan rendah (S03) dalam menyelsaikan masalah fungsi kuadrat adalah adalah membaca masalah terlebih dahulu masalah sampai paham. Saat dikonfirmasi dengan wawancara, subjek menjelaskan bahwa saat diberikan masalah fungsi kuadrat yang dilakukan adalah memahami masalah dan membaca satu kali. Hal ini sejalan dengan langkah pertama pemecahan masalah Krulik dan Rudnick (Ma'rufi, 2015) yaitu Read and Think yang berarti membaca dan berpikir. Pendapat ini sejalan juga dengan hasil penelitian Meilando, Idris \& Murdiana (2017) menyatakan bahwa siswa berkemampuan matematika rendah melakukan pembacaan masalah secara berulang serta menggunakan pengetahuannya dalam memahami masalah.

Subjek S03 melewatkan menulis apa yang diketahau dan apa yang ditanyakan dari masalah fungsi kuadrat yang berikan. ketika dikonfirmasi dengan wawancara, subjek menjelaskan bahwa subjek tidak terbiasa menuliskan apa yang diketahui dan apa yang ditanyakan ketika menjawab suatu soal. Dengan kata lain subjek terbiasa melangsungkan proses pencarian jawaban. Tetapi ktika ditanya subjek menjawab dengan tepat apa yang diketahui dan apa yang ditanyakan yaitu yang diketahui adalah jarak besi penopang, panjang besi terbesar. yang ditanyakan dalam soal yaitu Persamaan fungsi kuadrat, panjang besi 
penopang. Hal ini sejalan dengan langkah pertama pemecahan masalah Krulik dan Rudnick (Ma'rufi, 2015) yaitu Read and Think yang salah satu indikatornya adalah menyebutkan apa yang diketahui dan ditanyakan. Pernyataan ini juga didukung oleh Hasil penelitian Fahrudin, Mustangin, \& Faradiba (2021) yang meyimpulkan bahwa siswa berkemampuan matematika rendah mampu menyebutkan apa yang diketahui dan apa yang ditanyakan dari masalah yang diberikan.

Subjek S03 melakukan langkah mengeksplorasi masalah fungsi kuadrat langsung menggunakan rumus. Ketika wawancara, subjek S03 menjelaskan bahwa subjek mengeksplorasi masalah fungsi kuadrat langsung menggunakan rumus karena data mengenai apa yang diketahui sudah cukup untuk menjawab masalah apa yang ditanyakan. Dengan kecukupan data itu, subjek S02 langsung melanjutkan langkah menjawab masalah mengunakan rumus tersebut. Pernyataan ini juga didukung dengan hasil penelitian hasil penelitian Fahrudin, Mustangin, \& Faradiba (2021) yang meyimpulkan bahwa siswa berkemampuan matematika sedang kurang mampu mengeksplosari data-data dari masalah yang diberikan.

Subjek S03 menggunakan strategi penyelesaian masalah dengan menggunakan rumus fungsi kuadrat. Hal ini dapat dilihat dari hasil tes berikut:

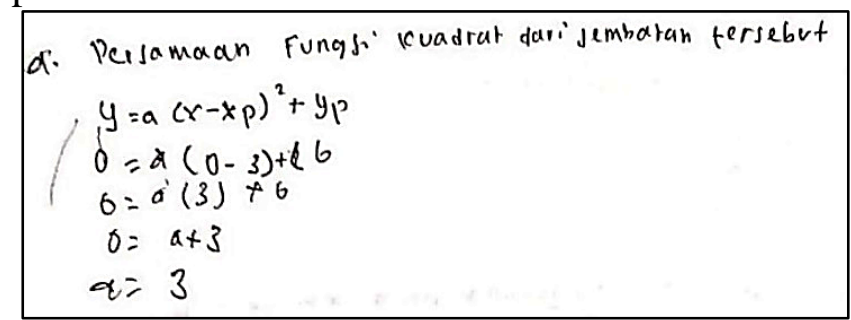

\section{Gambar 7. Subjek S03 memilih stategi penyelesaian masalah}

Pada saat wawancara, subjek S03 menyatakan bahwa menggunaan rumus fungsi kuadrat untuk menyelesaikan masalah yang diberikan. Subjek merencakan langkah penyelesaian masalah dengan cara mencari persamaan fungsi kuadrat dengan menggunakan subtitusi nilai. Subjek mengenal berbagai makna dan interpretasi konsep fungsi kuadrat yaitu bahwa untuk mencari panjang besi keseluruhan dengan memasukkan nilai titik yang sudah di sesuaikan dengan gambar ke dalam rumus fungsi kemudian dijumlahkan.. Hal ini sesuai dengan langkah penyelesaian Krulik \& Rudnik (Ma'rufi, 2015) yaitu Select a plan yang berarti memilih sustu strategi. Pernyataan ini juga didukung hasil penelitian Meilando, Idris \& Murdiana (2017) yang menyimpulkan bahwa subjek berkemampuan matematika rendah memiliki rencana pemecahan masalah dengan menggunakan rumus.

Subjek S03 mencari suatu solusi dari masalah dengan cara melakukan perhitungan aljabar. Hal ini dapat dilihat dari hasil tes berikut:

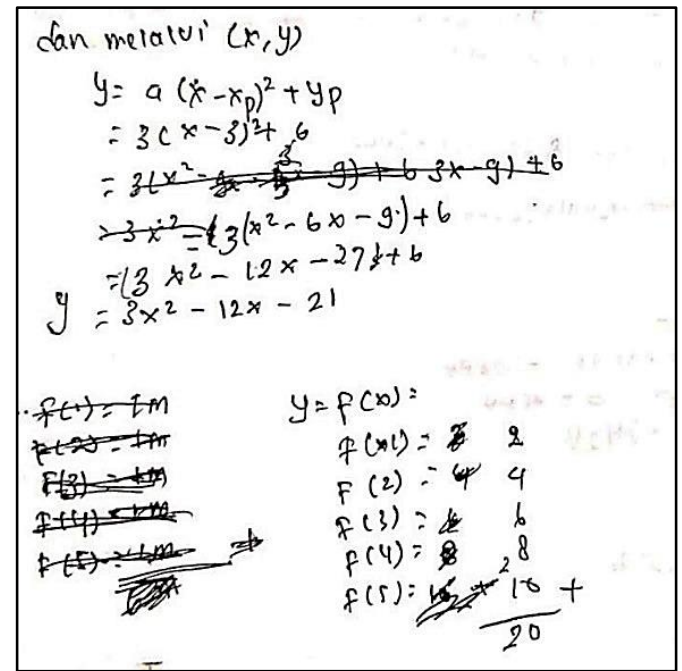

Gambar 8. Subjek S03 mencari suatu jawaban 
Saat dikonfirmasi dengan wawancara subjek S03 menjelaskan bahwa subjek melaksanakan langkah penyelesaian masalah sesuai dengan rencana awal, menggunakan rumus fungsi kuadrat dan subtitusi nilai. Subjek melakukan perhitungan aljabar yaitu melakukan perhitungan matematis terhadap rumus fungsi yang telah ditulis dan menghasilkan jawaban yang salah. Kesalahan perhitungan disebabkan karena subjek kurang teliti dalam mengerjakan. Dapat dilihat coretan-coretan dalam pengerjaan yang menunjukkan subjek dalam kondisi binggung atau salah perhitungan. Hal ini sesuai dengan langkah penyelesaian Krulik \& Rudnik (Ma'rufi, 2015) find a answer yaitu mencari suaru jawaban atau solusi dari masalah yang diberikan walaupan jawaban nnya salah. Pendapat ini juga sejalan hasil penelitian Fahrudin, Mustangin, \& Faradiba (2021) yang meyimpulkan bahwa siswa berkemampuan matematika rendah kurang mampu dalam menyelesaikan masalah.

Subjek S03 melewatkan langkah meninjau kembali hasil jawaban yang diperoleh. Hal ini diketahui dari hasil wawancara kepada subjek. Subjek menjelaskan bahwa subjek tidak mengecek ulang jawaban karena waktu pengerjaan sudahhampir habis dan ditambah kondisi pikiran yang sudah stuck. Pernyataan ini juga didukung dengan hasil penelitian Meilando, Idris \& Murdiana (2017) subjek berkemampuan matematika rendah tidak melakukan pemeriksaan kembali hasil pekerjaannya.

\section{KESIMPULAN}

Berdasarkan hasil analisis data dan pembahasan, peneliti menyimpulkan bahwa (1) Profil pemahaman matematis berkemampuan matematika tinggi dalam menyelesaikan masalah fungsi kuadrat adalah Subjek berkemampuan matematika tinggi dalam menyelesaiakan masalah adalah membaca masalah sampai paham, menuliskan dengan benar apa yang diketahui dan ditanyakan, melakukan eksplorasi masalah dengan tepat, memilih strategi penyelesaian masalah dengan tepat, menacari jawaban dengan melalukan perhitungan aljabar dengan tepat serta melakukan pemeriksaan jawaban kembali dari solusi yang diperoleh. (2) Profil pemahaman matematis berkemampuan matematika sedang dalam menyelesaikan masalah fungsi kuadrat adalah Subjek berkemampuan matematika sedang dalam menyelesaiakan masalah adalah membaca masalah sampai paham, menyebutkan dengan benar apa yang diketahui dan ditanyakan, melewatkan eksplorasi masalah, menacari jawaban dengan melalukan perhitungan aljabar walaupun diperoleh jawaban yang kurang tepat serta tidak melakukan pemeriksaan jawaban kembali karena waktu yang tidak cukup. (3) Profil pemahaman matematis berkemampuan matematika rendah dalam menyelesaikan masalah fungsi kuadrat adalah subjek berkemampuan matematika rendah dalam menyelesaiakan masalah adalah membaca masalah sampai paham, menyebutkan dengan benar apa yang diketahui dan ditanyakan, melewatkan eksplorasi masalah, menacari jawaban dengan melalukan perhitungan aljabar namun diperoleh jawaban yang kurang tepat serta tidak melakukan pemeriksaan jawaban kembali karena sudah stuck.

Berdasarkan hasil penelitian maka rekomendasi yang diberikan adalah (1) Guru dalam melaksanakan pembelajaran matematika dikelas hendaknya memperhatikan kemampuan matematika siswa. (2) Guru dalam merancang pembelajaran yang berdasarkan pemecahan masalah hendaknya memperhatikan pemahaman matematis siswa. (3) Dalam melakukan penelitian lanjutan, peneliti selanjutnya disarankan menggali informasi yang mendalam tentang pemahaman matematis siswa dalam menyelesaikan masalah berdasarkan kemampuan matematika.

\section{DAFTAR PUSTAKA}

Fahrudin, N., Mustangin, \& Faradiba, S.S. (2021). Analisis Kemampuan Pemecahan Masalah Kontekstual Siswa SMP Ditinjau dari Kemampuan Matematika. JP3, 16(19), 10-19. 
Hendriana, H,, Rohaeti,E.E., \& Sumarmo, U. (2017). Hard Skills dan Soft Skills Matematik Siswa. Bandung: Refika Aditama.

Ibrahim \& Suparni. (2012). Pembelajaran Matematika Teori dan Aplikasinya. Yogyakarta: Suka Press UIN Sunan Kalijaga.

Irhamna. (2017). Efektivitas Penggunaan Strategi Krulik dan Rudnick Dalam Meningkatkan Kemampuan pemecahan Masalah Matematis. SEMNASTIKAUNIMED, 321-325

Ma'rufi. (2015). Pengajuan dan Pemecahan Maslah Matematika. Bandung: Pustaka Ramadhan.

Mairing, J.P. (2018). Pemecahan Masalah Matematika Cara Siswa Memperoleh Jalan Untuk Berpikir Kreatif dan Sikap Positif. Bandung: Alfabeta

Meilando, R., Idris, M., \& Murdiana, I.Y. (2017). Profil Pemecahan Masalah Aritmatika Sosial Siswa Kelas VIII SMP Labschool Untad Palu Ditinjau dari Kemampuan Matematika. Jurnal Elektronik Pendidikan Matematika Tadulako, 5(2), 213-229.

Rochim, A., Herawati, T., \& Nurwiani, N. (2021). Deskripsi Pembelajaran Matematika Berbantuan Video Geogebra dan Pemahaman Matematis Siswa pada Materi Fungsi Kuadrat. Mosharafa: Jurnal Pendidikan Matematika, 10(2), 269-280.

Rochim, A. (2021). Profil Komunikasi Matematis Siswa Dalam Menyelesaikan Masalah Berdasarkan Tipe Kepribadian Ekstrovert dan Introvert. CORCYS: Prosiding Conference on Research and Community Services, 3(1), 72-83.

Siki, D., Djong, K.D., \& Jagom, Y.O. (2021). Profil Pemahaman Konsep Matematika Siswa SMP dalam Menyelesaikan Masalah Matematika. Leibniz: Jurnal Matematika, 1(1), 3643.

Soedjadi. (2007). Masalah Kontekstual Sebagai Batu Sendi Matematika Sekolah. Surabaya: Unesa.

Solso, R.L., et al. (2019). Psikologi Kognitif. Edisi Kedelapan (diterjemahkan oleh Rahardanto, M. \& Batuadji, K.). Jakarta: Erlangga.

Susanto, H.A. (2015). Pemahaman Pemecahan Masalah Berdasarkan Gaya Kognitif. Yogyakarta: Deepublish. 